\title{
Effects of Probiotics Diet Fed Myxcobacteria (JCH-04) on Survival, Growth, Digestive Enzymes Activities and Aquatic Environment in Grass Carp (Ctenopharyngodon idellus)
}

\author{
J. CHEN; X. H. LIU; J. B. JIA * \\ Department of Biology Engineering, Huaiyin Institute of Technology, Huai’an 223001, China \\ *Corresponding author: jiajianbo@hyit.edu.cn
}

Keywords: microecological preparation; grass carp; growth feature; digestive enzyme; humoral immunity

\begin{abstract}
In the paper, under simulated culture conditions, the effect of myxobacteria microecological preparation $\mathrm{JCH}-04$ on the growth, digestive enzyme and humoral immunity of grass carp were studied, at the same time, the removal effect of that on $\mathrm{NH}_{4}{ }^{+} \mathrm{N}^{-} \mathrm{NO}_{2}{ }^{-}-\mathrm{N}$ and COD of aquaculture water was assessed. Feeding method and added amount were defined. The research provided a theoretical basis for the application of microecological preparation on aquaculture and water purification.
\end{abstract}

\section{Introduction}

Microorganisms play an important role in direct or indirect ways in any aquatic ecosystem. At present, the use of antibiotics in aquaculture is restricted in many countries because of the potential appearance of antibiotic-resistant bacteria, which can negatively impact not only the cultured animals but also humans ${ }^{[1]}$. Biological control (biocontrol), defined as the utilisation of natural enemies to reduce the damage caused by noxious organisms to tolerable levels, could effectively prevent disease ${ }^{[2-3]}$. The concept of biocontrol in aquaculture has included probiotic approaches, defined as the use of a non-digestible food ingredient or live microorganismls that are helpful to the health of the host by stimulating the growth and/or activity of bacteria in the intestinal tract and adjusting gut microbial balance of the host organism ${ }^{[4-11]}$. Therefore the probiotics has been used act as a new type feed additive to alternatively stimulate the growth of beneficial bacteria and to restrain that of the pathogenic bacteria ${ }^{[12]}$. Shigeki Dan (2015) ${ }^{[1]}$ demonstrated that probiotic strains that exhibited high probiotic potential in in vitro experiments could inhibit larval necrosis symptoms in the seed production experiments. Probiotic could increase significantly protease and a-amylase activities in TG described by Cheng Fang (2015) ${ }^{[13]}$. The use of probiotics in the culture of aquatic species has been reported: improvement of growth performance ${ }^{[14-15]}$, digestibility coefficients of nutrients and the survival of aquatic livestock [16] and the activities of digestive enzymes ${ }^{[17]}$. However, the use of myxcobacteria and its influence on aquatic environment have not been reported. Therefore, the effects of probiotics diet fed myxcobacteria (JCH-04) on survival, growth, digestive enzymes activities and aquatic environment in grass carp (Ctenopharyngodon idellus) were carried out.

\section{Experimental Procedure:}

\section{Diet Preparation}

The composition of the experimental diets is: fish meal 8\%; peanut meal 20\%; soybean meal $11 \%$; rapeseed meal $30 \%$; puffing soybean powder $5 \%$; wheat middling $20 \%$;rice bran $2 \%$;salt $0.5 \%$; vitamin B-complex mix 0.5\%; mineral complex mix 2\%; plant oil 1\%. Different concentration of probiotics of JCH-04 compound microcapsule preparation $(0.1 \%, 0.2 \%, 0.4 \%)$ was mixed with the dough and the diets were pelletized $2 \mathrm{~cm}$ in diameter with hand pelletizer.

\section{Feeding Experiment}

Eight cement ponds were used as experimental ponds, of which one served as control, which devoid 
of probiotics (0\%) and others were as experimental ponds. Cement pond with $750 \mathrm{~L}$ water were 2.0 $\mathrm{m}$ length, $0.5 \mathrm{~m}$ breadth, $1.5 \mathrm{~m}$ height, in which aeration pump was allocated respectively. During the duration of the feeding trial, water was supplied to the fixed level to remedy the loss of water. 5 $\mathrm{mL}$ JCH-04 compound microcapsule preparation was periodically put into in $1 \mathrm{~m}^{3}$ water of experimental groups every 10 days. 40 grasscarp seedlings with the weight range of $5.50 \pm 0.10 \mathrm{~g}$ respectively were maintained in every pond.

The experimental groups were fed with the respective concentration of JCH-04 compound microcapsule incorporated diets $(0.1 \%, 0.2 \%, 0.4 \%)$. The feeding was adjusted to two times a day (7:00 am and 4:00 pm). The daily ration was given at the rate of $1.5 \%$ of the body weight of grasscarp seedlings. Grasscarp seedlings were starved for $24 \mathrm{~h}$ before and after the feeding experiment. The feeding experiment was carried out for 30 days. During the experiment, health status of fish, daily ration and death no. were recorded.

\section{Growth Study}

After the experiment, the growth parameters were individually calculated by the following equtions, such as survival (S), weight gain rate (WGR) and feed conversion rate (FCR).

Survival (\%) $=\frac{\text { Tota } \ln \text { o.oflivefishes }}{\text { Tota } \ln \text { o.ofinitialfishes }} \times 100$

Weight gain Rate $(\%)=($ Finial weight - Initial weight $) \times 100 /$ Finial weight

feed conversion rate $(\mathrm{FCR})=$ Total feed intake(g)/Total weight gain $(\mathrm{g})$

\section{Water Parameters Determination}

Water parameters determination was carried out every 10 days. The first water sample was collected following adding JCH-04 compound microcapsule and other samples were collected prior to adding probiotics. Water collecting depth was $20 \mathrm{~cm}$ above the bottom of the pond and water temperature maitained at 25-30 ${ }^{\circ} \mathrm{C}$. Samples were qualitatively analysed for five different physiochemical parameters: $\mathrm{pH}$, chemical oxygen demand (COD), dissolved oxygen (DO), $\mathrm{NH}_{4}{ }^{+}-\mathrm{N}$, $\mathrm{NO}_{2}-\mathrm{N}$.

\section{Digestive Enzymatic Activities and IgA Measurement}

Activities of digestive enzymes of samples from viscus(liver and pancreas), serum and intestinat tract, such as lysozyme (LSZ), superoxide dismutase(SOD), alkaline phosphatase(ALP), catalase(CAT), protease, amylase and lipase were assayed.

Whole bowel segments and viscus samples were collected from five fish. Viscus samples and intestinal sampled were washed with cold deionized water $\left(4^{\circ} \mathrm{C}\right)$ to remove most of the mucus and surface-dried with filter paper. Homogenized in cold sodium phosphate buffer $\left(0.1 \mathrm{M}, \mathrm{pH} 7.0,4^{\circ} \mathrm{C}\right)$ by a ratio of $1: 9(\mathrm{~m} / \mathrm{v})$. The homogenate was then centrifuged at $4{ }^{\circ} \mathrm{C}$ at $10,0009 \mathrm{~g}$ for $30 \mathrm{~min}$. The supernatant containing enzymes was stored at $-80^{\circ} \mathrm{C}$ prior to the analysis ${ }^{[13]}$. After the blood was collected and immediately inclined-placed, serum was precipitation for IgA measurement.

\section{Data Analysis}

All experiments were run in triplicate, and subjected to analysis of variance (ANOVA). The least significant different (LSD) procedure was used to test for difference between means (significance was defined at $\mathrm{P}<0.05$ ) (spss 11.5 software).

\section{Results and Discussion:}

\section{Growth Performance}

At the end of feeding experiments, results of growth performance are shown Table 1. Growth performance improved with the increasing of adding content of probiotics JCH-04. The WGR and S were higher in experimental groups than the control grouop. Grassfish fed with $0.4 \%$ JCH-04 had 
maximum DWGR of $1.82 \%$, the other groups, such as $0.1 \%$ and $0.2 \%$ deserved $1.21 \%$ and $1.46 \%$ DWGR, significantly higher than control group of $0.92 \%$. Whereas, the $0.4 \%$ fed diet gained the lower level of S (68.5\%) and the highest FCR of 3.64\%. Myxcobacteria has been shown to improve the performance for fish growth. The similar conclusion was obtained from the studies, such as Tilapia of ${ }^{[18]}$, catfish and carp ${ }^{[19]}$.

Table 1 Effects of dietary probiotics on growth performance in grassfish.

\begin{tabular}{|l|l|l|l|l|l|l|}
\hline $\begin{array}{l}\text { parameter } \\
\text { s }\end{array}$ & $\begin{array}{l}\text { Final } \\
\text { weight(g) }\end{array}$ & $\begin{array}{l}\text { Initial } \\
\text { weight(g) }\end{array}$ & WGR(\%) & $\begin{array}{l}\text { DWGR } \\
(\%)\end{array}$ & S (\%) & FCR (\%) \\
\hline Control & 35.10 & 5.50 & 501.82 & 0.92 & 68.5 & 3.64 \\
\hline $0.1 \%$ & 41.90 & 5.60 & 648.21 & 1.21 & 88.8 & 2.95 \\
\hline $0.2 \%$ & 49.40 & 5.60 & 782.14 & 1.46 & 90.7 & 2.30 \\
\hline $0.4 \%$ & 60.10 & 5.50 & 992.73 & 1.82 & 96.2 & 1.84 \\
\hline
\end{tabular}

\section{Digestive Enzymatic Activities}

As is shown in Table2, the amount of LSZ,SOD,ALP,CAT,IgM increasing along with the number of dietary probiotics. It may possibly because the myxobacteria motivates some related zymogen, so that the immune protection rate of grassfish gradually improved, and significantly higher than that of control group. When the adding amount was the highest dose group $0.4 \%$, grassfish protection rate arrived at $68 \%$. Wu (2004) [20] showed that the nonspecific immune of the aquatic animal can be improved by dietary probiotics. Chen(2009)[21]found that adding a certain dose of Bacillus subtilis microcapsule preparation in feed can strengthen the immunity and disease resistance of Chinese Mitten Crab Eriocheir sinensis. Immunoglobulin can resist various diseases to protect animals. In bony fish, there are two kind of immunoglobulin, respectively belonging to IgM and IgD ${ }^{[22]}$, But only IgM owns the similarity in the structure and physiological characteristics. The IgM exists in the blood and other body fluids which is the effector molecule of immune. Under the conditions of this experiment, the addition of myxobacteria in dose group $0.2 \%$, can significantly improve the fish plasma levels of IgM, while in the control group, because of the original IgM in fish body, without any agent it also has certain immune protection rate; when the agent added, the immune protection rate increased. Therefore, the dietary probiotics is a effective immune stimuli. Reflected from the humoral immune indices, myxobacteria added could improve the ability of immune in grassfish.

Table 2 Effects of dietary probiotics on immunology activities in grassfish.

\begin{tabular}{|l|l|l|l|l|l|l|}
\hline $\begin{array}{l}\text { paramete } \\
\text { rs }\end{array}$ & $\begin{array}{l}\text { ALP(U/g } \\
\text { (S }\end{array}$ & $\begin{array}{l}\text { CAT(U/m } \\
\text { g) }\end{array}$ & $\begin{array}{l}\text { SOD(U/m } \\
\text { g) }\end{array}$ & $\begin{array}{l}\text { LSZ(U/m } \\
\text { g) }\end{array}$ & IgM( $\mu \mathrm{g} / \mathrm{ml})$ & $\begin{array}{l}\text { Immne } \\
\text { protection } \\
\text { rate(\%) }\end{array}$ \\
\hline Control & 18.34 & 0.45 & 18.32 & 0.110 & 0.18 & 13 \\
\hline $0.1 \%$ & 19.98 & 0.63 & 19.87 & 0.134 & 0.37 & 42 \\
\hline $0.2 \%$ & 23.70 & 0.69 & 19.98 & 0.187 & 0.59 & 56 \\
\hline $0.4 \%$ & 26.46 & 0.88 & 21.35 & 0.210 & 0.58 & 68 \\
\hline
\end{tabular}

Recent studies show that the SOD and CAT activity have a close relation to biological immune level, the changes of its activity could reflect the function and health status of grassfish measured by immune status indicator. Add dietary probiotics directly into the grassfish aquaculture could significantly increased the activity of superoxide dismutase, while enhancing the nonspecific immune level of grassfish. In this experiment, CAT and SOD activity in $0.1 \%$ and $0.2 \%$ had no obvious difference between the added group, significantly higher than that in control group, lower than the $0.4 \%$ groups at the same time. While ALP and LSZ activity rising with the amount of dietary probiotics added, indicating that ALP and LSZ activity of probiotics can promote the grassfish. Direct addition of dietaty probiotics to the water body is simple and easy and is a 
practicable method to promote the shrimp immunity.

According to Table 3, the amylase activity of grassfish rises with dietary probiotics and the quantity and control group significantly increased. Lipase and protease activity with dirtary probiotics dosage increased compared with the control group did not significantly increase, when adding dose group $0.2 \%$, lipase and protease activity basically has reached the maximum and adding $0.4 \%$ dietary probiotics group, the increase of lipase and protease activity of grassfish tend to be gentle. When the addition amount was $0.2 \%$, lipase and protease activity reached 368U/g, 178 U/g. From the level of digestive enzyme of grassfish, adding the myxobacteria can significantly improve grassfish amylase

activity and the activity of lipase and protease enhanced to some extent.

Table 3 Effects of dietary probiotics on intestinal digestive enzyme activities in grassfish.

\begin{tabular}{|l|l|l|l|}
\hline parameters & $\begin{array}{l}\text { Protease(U/ } \\
\mathrm{mg})\end{array}$ & $\begin{array}{l}\text { Lipase(U/m } \\
\mathrm{g})\end{array}$ & $\begin{array}{l}\text { Amylse(U/m } \\
\mathrm{g})\end{array}$ \\
\hline Control & 0.16 & 0.33 & 2.52 \\
\hline $0.1 \%$ & 0.16 & 0.33 & 2.68 \\
\hline $0.2 \%$ & 0.17 & 0.37 & 3.26 \\
\hline $0.4 \%$ & 0.18 & 0.38 & 4.57 \\
\hline
\end{tabular}

\section{Effect of Dietary Probiotics and Liquid Agent to Aquaculture Water Environment}

Aquaculture is an important environment for the growth of fish and it is essential to the growth of fish, so how to regulate the water quality indicators and keep it in a reasonable range is a key technical problem. Probiotics JCH-04 live bacteria preparation has an obvious effect on water quality adjustment.

Through the influence of $\mathrm{pH}$ analysis, the $\mathrm{pH}$ of control group is slightly higher than the experimental group, inoculum addition amount has little effect on aquaculture water(Table 4). The COD of test group is far higher than that of the control group, with the increasing amount of added inoculants on the removal rate of COD increased in aquaculture water, adding $0.4 \%$ is the best. From the final test data of COD, in addition to control group, are less than $6.00 \mathrm{mg} / \mathrm{L}$ and reaching to a good water quality standard. The test group $\mathrm{NH}_{4}{ }^{+}-\mathrm{N}$ and $\mathrm{NO}_{2}-\mathrm{N}$ is far lower than that of control group, with increasing amount of added inoculants on the removal rate of $\mathrm{NH}_{4}{ }^{+}-\mathrm{N}$ and $\mathrm{NO}_{2}-\mathrm{N}$, adding $0.4 \%$ is the best. From the final test group, $\mathrm{NH}_{4}{ }^{+}-\mathrm{N}$ and $\mathrm{NO}_{2}-\mathrm{N}$ were less than $0.60 \mathrm{mg} / \mathrm{L}$, achieving water quality standard.

Table 4 Effects of dietary probiotics and liquid agent on aquaculture water environments.

\begin{tabular}{|l|l|l|l|l|}
\hline $\begin{array}{l}\text { parameter } \\
\mathrm{s}\end{array}$ & $\mathrm{pH}$ & $\mathrm{COD}(\mathrm{mg} / \mathrm{L})$ & $\begin{array}{l}\mathrm{NH}_{4}{ }^{+}-\mathrm{N} \\
(\mathrm{mg} / \mathrm{L})\end{array}$ & $\mathrm{NO}_{2}{ }^{-}-\mathrm{N}$ \\
\hline Control & 7.9 & 26.7 & 6.40 & 6.85 \\
\hline $0.1 \%$ & 7.7 & 6.5 & 0.38 & 0.52 \\
\hline $0.2 \%$ & 7.6 & 5.8 & 0.21 & 0.24 \\
\hline $0.4 \%$ & 7.7 & 4.5 & 0.12 & 0.18 \\
\hline
\end{tabular}

There are a lot of probiotics which have the advantages of low cost, no toxic side effect, no drug residue, no drug resistance and other advantages in aquaculture breeding and can be used to improve the ecological environment, purifying water quality. Probiotics widely used as a feed additive now have become the ideal product replacing antibiotics.

Study of myxobacteria is still restricted in its own properties, as the application of probiotics in aquaculture has not been reported; this experiment is the micro ecological feed additive for aquaculture use. Results show that adding $0.2-0.4 \%$ microcapsule preparation in the feed, at the same time every 10 days to add a certain amount of bacteria in water suspension, can effectively improve the immune ability and the level of digestive enzymes of grassfish. From the growth of 
grassfish, weight-gaining per day was significantly higher than the control group, the feed conversion rate decreased gradually. At the same time, $\mathrm{NO}_{2}-\mathrm{N}, \mathrm{NH}_{4}{ }^{+}-\mathrm{N}$ and COD in aquaculture water can be removed effectively, improving the environmental impact of aquaculture water, reaching a good application effect.

\section{Conclusions}

This paper made a simulation test on the effect of probiotics on the grassfish, with $0.4 \%$ of the probiotic was added to the best. Myxobacteria composite formulations of JCH-04 can effectively improve the grassfish growth performance, immune level and digestive enzyme levels, also have certain effect on water purification

\section{Acknowledgements}

This work was financially supported by the Academic Scientific and Technological Industrialization Projects of Jiangsu Education Department (JHB2012-59).

\section{References}

[1] D. Shigeki and H. Katsuyuki:' Evaluation of the effects of probiotics in controlling bacterial necrosis symptoms in larvae of the mud crab Scylla serrata during mass seed production', Aquacult Int., 2015, 23, 277-296.

[2] M. Maeda, K. Nogami, M. Kanematsu and K. Hirayama:'The concept of biological control methods in aquaculture', Hydrobiologia, 1997, 358, 285-290.

[3] K. Nogami, K. Hamasaki, M. Maeda and K. Hirayama:'Biocontrol method in aquaculture for rearing the swimming crab larvae Portunus trituberculatus', Hydrobiologia, 1997, 358, 291-295.

[4] J. L. Balca'zar, I. Blas, I. Ruiz-Zarzuela, D.Cunningham, D. Vendrell and J. L. Mu'zquiz:'The role of probiotics in aquaculture', Vet Microbiol, 2006,114, 173-186.

[5] R. Fuller R:’Probiotics in man and mammals’, J Appl Bacteriol, 1996, 66, 365-378.

[6] F.J. Gatesoupe, “The use of probiotics in aquaculture”, Aquaculture, 1999,180, 147-165.

[7] A.Irianto, B. Austin:’Probiotics in aquaculture’, J Fish Dis, 2002, 25, 633-642.

[8] A. Kesarcodi-Watson, H.Kaspar, M.J.Lategan, L.Gibson:'Probiotics in aquaculture: the need, principles and mechanisms of action and screening processes', Aquaculture, 2008,272,1-14.

[9] L.Verschuere, G. Rombaut, P. Sorgeloos, W. Verstraete:'Probiotic bacteria as biological control agents in aquaculture', Microbiol Mol Biol Rev, 2000,64, 655-671.

[10] Q. Ai, H. Xu, K. Mai, W. Xu, J. Wang, W. Zhang:'Effects of dietary supplementation of Bacillus subtilis and fructooligosaccharide on growth performance, survival, non-specific immune response and disease resistance of juvenile large yellow croaker, Larimichthys crocea', 2011,Aquaculture, 317, 155-161.

[11] D.L. Merrifield, A. Dimitroglou, A. Foey, S.J. Davies, R. Baker, J. Bøgwald, M. Castex, E. Ringø:'The current status and future focus of probiotic and prebiotic applications for salmonids', Aquaculture,2010,302, 1-18.

[12] J.W.Sissons:'Potential of probiotic organisms to prevent diarrhoea and promote digestion in farm animals', Journal of Science Food and Agriculture, 1989, 49, 1-13.

[13] C. Fang, M.Y.Ma, H. Ji, T.J. Ren, S. D. Mims:'Alterations of digestive enzyme activities, intestinal morphology and microbiota in juvenile paddlefish,Polyodon spathula, fed dietary probiotics’, Fish Physiol Biochem, 2015,41, 91-105. 
[14] S.Ghosh, A. Sinha, aC. Sahu:'Effect of probiotic on reproductive performance in female live bearing ornamental fish', Aquaculture Research, 2007,38, 518-526.

[15] A. Panigrahi, I.S. Azad:'Microbial intervention for better fish health in aquaculture: The Indian scenario', Fish Physiology and Biochemistry, 2007,33, 429-440.

[16] Z.L.Heizhao, G. Zhixun, Y. Yingying, Z. Wenhu, and J.L. Zhuojia:'Effect of dietary probiotics on apparent digestibility coefficients of nutrients of white shrimp, Litopenaeus vannamei Boon', Aquaculture Research, 2004, 35, 1441-1447.

[17] C. Seenivasan, P.S. Bhavan, S. Radhakrishnan, T. Muralisankar, G.Immanuel, V. Srinivasan, and N. Manickam:'Effect of Saccharomyces cerevisiae on survival, growth, biochemical constituents and energy utilization in the prawn Macrobrachium rosenbergii', International Journal of Applied Biology and Pharmaceutical Technology,2013,4, 39-47.

[18] Q.H.Yang, X.Q.Zhou:'Effect of Probiotics on Growth, Feed Conversion and Disease Resistance in Oreochromis mossambicus', GuangDong Feed, 2009,18, 24-27.

[19] L. Wu, P. F.Chen:'Effect of EM(Effective Microognisms) on the Growth and the Blood Parameters of Silurus Meridionalis and Cyprimus Carpio', Journal of Southwest China Normal University(Natural Science Edition), 2007,32, 82-86.

[20] Z.X.Wu, X.X.Chen, L.J.Li:'Effect of Probiotics on the Immune Capacity of Silver Crucian Carp', Reservoir Fisheries, 2004, 24, 67-68.

[21] W.D. Chen, Y. Li, X.J. Hao, Y.G. Liu, H.Y. Liu:'Effect of Lyophilized Powder of Alginate Microcapsules on Immune Ability and Disease Resistance of living Bacillus subtilis of Chinese Mitten Crab(Eriocheir sinensis)', China Feed, 2009,5, 33-36.

[22] L. Sha, M. Guan, W.T. Guo, H. T. Qu:'Effects of Probiotics on Growth, and Activities of Digestive Enzymes and Enzymes Related to Non-specific Immunity in Chinese Sturgeon', Chinese Journal of Fisheries, 2014, 1, 38-45. 